УДК 378.881.111.1

\title{
МЕТОДИ ПОЗИТИВНОГО МОТИВУВАННЯ УЧНІВ ПОЧАТКОВОЇ ШКОЛИ (ЗА МЕТОДИКОЮ А. В. ФРИСБІ)
}

\author{
Бабенко Т. В. \\ babenkotamara22@ukr.net \\ Київський наиіональний університет імені Тараса Шевченка \\ Дата надходження 21.11.2018. Рекомендовано до друку 12.12.2018.
}

\begin{abstract}
Анотація. Успішне й продуктивне навчання учнів початкової школи іноземної мови неможливе без створення позитивної мотивації. У пошуках методів і способів мотивування школярів не варто відмовлятися від досвіду, який був накопичений талановитими педагогами минулого. Одним з них $є$ А.В. Фрисбі, англійський педагог й методист, теоретик і практик навчання англійської мови як іноземної для початківців. У статті проаналізовано методичні надбання А.В. Фрисбі щодо формування мовленнєвої й мовної компетентностей і послідовності, якої треба дотримуватися в процесі їх опанування. Поради педагога щодо навчання непідготовленого мовлення, використання англійської мови як "символу думки" й способів запобігання педагогічних помилок, які призводять до втрати позитивної мотивації, повністю збігаються з тими цілями, які стоять перед сучасним учителем. Актуальним для сьогодення є психологопедагогічний підхід А.В. Фрисбі до вивчення природи дитини й використання цих знань для створення сприятливої вмотивованої атмосфери на уроці англійської мови.
\end{abstract}

Ключові слова: формування позитивної мотивації, мовленнєві навички, непідготовлене мовлення, роль учителя, психологічно сприятлива атмосфера.

Бабенко Т. В. Киевский национальный университет имени Тараса Шевченко

Методы позитивной мотивации учащихся начальной школы (по методике А. В. Фрисби)

Аннотация. Успешное обучение иностранным языкам в начальной школе невозможно без создания позитивной мотивации. В поисках методов и способов мотивации учащихся не стоит отказываться от опыта выдающихся педагогов предыдущих поколений. Одним из них является А.В. Фрисби, английский педагог и методист, теоретик и практик обучения английскому языку как иностранному. В статье проанализированы его методические приёмы формирования речевой и языковой компетентностей. Советы Фрисби касаются последовательности формирования речевых компетентностей и методики обучения неподготовленной речи, а также использования английского языка “как символа мысли”. Его способы предупреждения педагогических ошибок, которые приводят к утрате позитивной мотивации, а также психолого-педагогический подход к изучению личности ученика являются особенно актуальными в свете тех задач, которые стоят перед современным учителем.

Ключевые слова: формирование позитивной мотивации, речевые навыки, неподготовленная речь, роль учителя, психологически благоприятная атмосфера.

Babenko T. V. Kyiv Taras Shevchenko National University

Methods of primary school pupils' positive motivation (based on A. W. Frisby's methodology)

Abstract. Introduction. Practical command of the English language is one of the priorities in modern primary school. Successful teaching of a foreign language to children is impossible without creating the atmosphere of positive motivation. Purpose. Considering the experience of the researchers and teachers of former generations as well as different approaches to language teaching may become very useful for the purpose of establishing positive motivation in the language classroom. Methods. The article provides the analysis of A. W. Frisby's methods of teaching English as a second language and the ways of motivating younger learners: his approaches to teaching the four basic skills (speaking, listening, reading, writing), principles of introducing language material (phonetics, vocabulary, grammar) and the role of the teacher in the language classroom. Results. A. W. Frisby's teaching methods were partially influenced by Dr. Charles C. Fries (Audioligualism), Dr. H. E. Palmer's works (Oral Approach), Structural Approach and the key ideas of a prominent linguist and philosopher of the language J. R. Firth whose works are still found to be inspiring. A. W. Frisby managed to enrich the above mentioned 
methods by applying pedagogical and psychological approaches to language teaching. He strongly believed that successful teaching and learning may be achieved only under the condition of motivating pupils by introducing familiar content into the language acquisition. But this motivation should be based on the knowledge of a child's personality, his home life and language abilities. Conclusion. A. W. Frisby introduced the procedure of teaching the four basic skills: listening, speaking, reading and writing, but the most attention was paid to listening and speaking. He considered teaching unprepared oral speech to be one of the factors that motivates young learners. A. W. Frisby's pieces of advice on taking into consideration children's different psychological, pedagogical and social characteristics will be of great use for contemporary foreign language teachers.

Key words: positive motivation forming, language skills, unprepared speech, teacher's role, psychologically favourable atmosphere.

Постановка проблеми. Концептуальні засади реформування української школи визначають десять компетентностей, якими мають оволодіти учні на кінець навчання, 3-поміж яких - спілкування іноземними мовами. У 2017-2018 навчальному році наказом Міністерства освіти і науки України були запроваджені зміни в навчальний процес з іноземних мов у початковій школі. В преамбулі до Методичних рекомендацій щодо організації навчального процесу 3 іноземних мов у 1-х класах експериментальних загальноосвітніх навчальних закладів наголошено на необхідності зацікавити учнів вивченням предмета, “викликати у них позитивне ставлення до предмета, вмотивовувати необхідність і значущість володіння іноземною мовою як неповторним засобом культурного спілкування" (Методичні рекомендації, 2017). Без володіння спільною мовою співпраця з країнами Свропи значно ускладнюватиметься. Оскільки такою спільною мовою на сьогоднішній день $є$ англійська, проблема формування позитивної мотивації у процесі іiї навчання набуває особливої актуальності.

Саме в початковій школі формується ставлення до предмета, яке іноді залишається на все життя. Впровадження комунікативного методу навчання іноземних мов, наявність широкого спектру підручників для будь-якого рівня знань, застосування сучасних технологій навчання значно збагатило методичний репертуар кожного вчителя щодо стимулювання пізнавальної діяльності молодших школярів. Проте методи, які започаткували й використовували видатні педагоги й методисти XX сторіччя в навчанні англійської мови як іноземної, стають у пригоді й сучасному вчителеві початкової школи.

Мета статті: розглянути методи створення позитивних мотивів як стимулів пізнавальної діяльності учнів у процесі формування мовленнєвої й мовної компетентностей англійською мовою (за досвідом англійського педагога й науковця А. В. Фрисбі) й довести їхню актуальність у контексті запровадження реформи початкової школи.

За визначенням Украӥнського педагогічного словника, мотивація - це “система мотивів, або стимулів, яка спонукає людину до конкретних форм діяльності або поведінки” (Гончаренко, 1997, с. 217). 3 цим визначенням погоджуються й білоруські науковці, окреслюючи мотивацію як систему мотивів, потреб, інтересів, прагнень, цілей, нахилів, мотиваційних установок або диспозицій, ідеалів тощо, що в найширшому сенсі розуміють як детермінацію поведінки взагалі (Рапацевич, 2010, с. 328 ). Мотивація навчання залежить від установок особистості учня на навчання: позитивних, які надають сил і натхнення (усвідомлення відповідальності за своє майбутнє, прагнення до пізнання нового, внутрішнє відчуття обов'язку перед батьками й суспільством) і негативних, які примушують виконувати навчальні завдання заради уникнення неприємних наслідків (Якобсон, 1969, сс. 227-229).

Методи стимулювання позитивних мотивів грунтуються на багатовікових дослідженнях філософів й педагогів минулого. Ще педагоги-гуманісти доби Відродження - Єразм Роттердамський та Франсуа Рабле - зазначали, що процес навчання має бути легким і приємним для дітей, таким, що розвиває їхню активність і самодіяльність. Ця ідея отримала свій розвиток у роботах педагога й філософа Песталоцці, який вважав, що дитина має почуватися в школі так само природно й вільно, як серед природи. У XX сторіччі окремі аспекти проблеми 
мотивації особистості досліджувались психологами й педагогами П.М. Якобсоном (Психологічні проблеми мотивації поведінки людини, 1969), В.І. Ковалевим (Мотиви поведінки і діяльності, 1988), А.К. Марковою, А.Б. Орловим, Л.М. Фрідманом (Мотивація навчання та іiї виховання у школярів, 1983), Л.В. Занковим (Навчання та розвиток, 1990), В.О. Сухомлинським (Сто порад вчителеві, 1977). Під впливом політичних процесів в Україні XXI сторіччя проблема мотивації вивчення іноземних мов набула нового значення, що викликало до неї інтерес молодих науковців - Г.Г. Волошина, Т.Е. Гончаренко, Ю.В. Холмакова, О.О. Малінко, І. Стецько, Н. Шеверун. Проте їхні праці торкаються, переважно, вивчення іноземного досвіду з питань мотивації студентів і розвитку мотивації у студентів галузевих закладів вищої освіти.

В аспекті позитивного мотивування процесу навчання іноземних мов вартує уваги спадщина англійського педагога і методиста А.В. Фрисбі (XX ст.), який виклав свої ідеї та практичний досвід навчання англійської мови в праці “Навчання англійської мови. Замітки та коментар про навчання англійської мови за кордоном” (1964). Книга зорієнтована на навчання дітей у Східній Азії, адже присутність англомовного військового контингенту на цих територіях сприяла пошукам продуктивних методів навчання місцевого населення англійської мови. Значний вплив на формування поглядів Фрисби справили Ч. Фриз і Г. Пальмер.

Треба відзначити, що на той час найзастосованішим був аудіолінгвальний метод навчання іноземних мов (Audioligualism), який розробили американські вчені Ч. Фриз і Р. Ладо в 194050 роках. Згідно з цим методом, навчання англійської мови як іноземної грунтувалося на таких принципах: 1) зорієнтованість на досягнення такого рівня знань, який уможливить використання англійської мови на підсвідомому рівні, як це відбувається у носіїв мови; 2) створення в класі тільки англомовного середовища; 3) використання для навчання говоріння стимулів, які передбачають негайну відповідь, без ії обміркування, що відбувається завдяки попередньому вивченню напам'ять діалогів і виконанню тренувальних вправ; 4) дуже стисле пояснення граматичного матеріалу, якщо в цьому виникає потреба; 5) дотримання в навчанні чотирьох видів мовленнєвої діяльності певної послідовності, притаманної рідній мові: сприйняття на слух, говоріння, читання, письмо (Чепмен, Рутледж, 2005, сс. 80-86).

Натомість у Британії 1930-1960 років набув розвитку започаткований прикладними лінгвістами ситуативний або усний підхід до вивчення іноземних мов (Situational or Oral Approach), який зберігав свою популярність до кінця 80-х років XX століття. Йому були притаманні такі риси: 1) першочергова увага приділялась формуванню навичок усного мовлення; 2) мовленнєва й мовна компетентності формувались лише засобами англійської мови; 3) ретельно добирались найуживаніші лексика й граматика для подальшого опрацювання в ситуаціях спілкування; 4) акцентувалась роль учителя (Celce-Mursia, 1991, pp. 6-7). На певному етапі розвитку ситуативний метод був збагачений за рахунок праць теоретика та філософа мови Дж.Р. Фірса (1950, сс. 37-52), який вважав, що мова є “збіркою подій”, які обговорюють співрозмовники. Тому, на його думку, лінгвісти мають замислитися над створенням таких "подій”, тобто над ситуаціями спілкування.

Методичні поради А.В. Фрисбі свідчать про те, що він наслідував ситуативний або усний метод. Запропонована ним послідовність оволодіння навичками мовленнєвої діяльності (“тренувальні усні вправи - читання вже знайомого мовного матеріалу - письмо”, а на пізніших етапах - “говоріння - написання творів - граматика") підтверджує те, що А.В. Фрисбі підтримує більшість принципів навчання англійської мови, притаманних цьому методу. Проте автор вносить своє бачення в його практичне застосування: по-перше, він пропонує його лише для дітей й, по-друге, збагачує цей метод, наголошуючи на виховних аспектах, а саме, на зацікавленні школярів процесом навчання й необхідності позитивного мотивування учнів. Отже, А.В. Фрисбі позиціонує себе як педагога у повному сенсі цього слова, для якого процес навчання є невіддільних від виховання. 
Говорячи про формування компетентності в говорінні, А.В. Фрисбі наголошує на тому, що вправляння у розмовному мовленні має розпочинатися якомога швидше, адже в іншому paзi, як застерігає А.В. Фрисбі, іноземна мова перетворюється на безглузде вивчення слів. Він намагався навчати вихованців "вдягати свої думки в англійську мову", використовувати iï як “символ думки", натомість перетворення іiі на "непотрібне словесне лушпиння", що призводить до виникнення в учнів стану фрустрації й усвідомлення непотрібності поставлених завдань. Услід за ситуативним методом, автор пропонує навчати розмовного мовлення на основі засвоєння мовних зразків: спочатку учні мають усвідомити їх значення, фонетично правильно промовляти запропоновані лексичні одиниці, а лише потім застосовувати в усному мовленні. У своій книзі А.В. Фрисбі дає відповідь на питання, як поряд з тренувальними вправами й «формуванням правильних мовних звичок» не загубити учнівську зацікавленість у вживанні мови як “засобу мислення” (Фрисбі, 1964, сс. 22).

Це переконання автора не суперечить сучасним методам навчання. Щодо мовленнєвих навичок, то наразі основний акцент також має бути зроблений на аудіюванні й говорінні, що цілком збігається з позицією автора, який вважав аудіювання першоджерелом отримання знань, важливим засобом формування правильних мовних навичок. Усне мовлення, на якому робить наголос А.В. Фрисбі, а особливо непідготовлене мовлення - $\epsilon$, на наш погляд, найулюбленішим видом роботи школярів, адже таке вправляння надає можливість відчути на практиці, що англійською мовою можна спілкуватися: поставити запитання про те, що тобі цікаво, а не до знайомого всім тексту; розповісти про актуальні події, що сталися у твоєму житті, а не у житті персонажа з чергового тексту. Власне, аудіювання й непідготовлене мовлення реалізують позитивні учнівські мотиви, заради яких вони приходять на перший урок іноземної мови.

Як будь-який досвідчений педагог, А.В. Фрисбі приділяє багато уваги тренуванню в непідготовленому мовленні. Але автор нагадує, що навчати говоріння треба на знайомій учневі тематиці, яка йому цікава й джерела якої - скрізь, навколо нас, варто лише прислухатися, про що розмовляють учні на перерві. Будь-який текст - 3 підручника, газети, реклами, концертної програми - може стати предметом дискусії. Учні залюбки обговорюватимуть події шкільного життя - контрольні роботи, спортивні змагання, концерти або поламане кимось крісло. Багатим джерелом розмовної тематики з наступним вправлянням у письмі є суспільні події, до яких потрібно готувати оголошення або розсилати запрошення. Отже, тем для непідготовленого мовлення - безліч. Головне - підтримувати під час обговорення дружню атмосферу й ініціативу учнів. Щоб завдання були досяжними й стимулювальними, вчителеві потрібно передбачати мовні труднощі, які можуть виникнути під час їх виконання, й попередньо надати відповідну підтримку у вигляді лексичних одиниць або граматичних структур. Така підготовка збереже увагу учня й стане запорукою його бажання і можливості виконати ту чи іншу вправу (Фрисбі, 1964, сс. 246-247).

Методичні поради автора не обходять й такого питання, як формування граматичної компетентності та місця граматики в навчальному процесі. А.В. Фрисбі наводить цікаві порівняння, називаючи мовлення “транспортом", за допомогою якого ми передаємо свої думки й почуття, у той час, як граматика є “двигуном", який заводить цей транспорт й підтримує його рух. Ось на яких положеннях грунтується його методична концепція: 1) фундаментом живого мовлення є розмовне, а не письмова форма; 2) живе мовлення не має бути статичною, воно постійно змінюється; 3) граматика не встановлює правила, вона лише помічає зміни у мові та реєструє їх 4) одиницею мовлення $\epsilon$ не слово, а словосполучення; 5) важливим $€$ порядок слів й те, як функціонують лексичні одиниці; 6) приклади $€$ важливішими за правила. Виходячи із зазначеної концепції, автор виокремлює три найважливіші характеристики англійської мови, опанування яких становить вивчення граматики: 1) порядок слів у реченні; 2) моделі речень; 3) структурні слова (Фрисбі, 1964, сс. 266-268). 
Щодо місця граматики, то автор однозначно стверджує, що граматика завжди слідує за видами мовленнєвої діяльності. Він порівнює цей процес з оволодінням рідною мовою, коли дитина навчається від дорослих певних мовленнєвих зразків, робить багато помилок й лише 3 часом опановує правила. На думку А.В. Фрисбі, дитині не потрібно виконувати багато граматичних вправ, проте він пропонує використовувати, по можливості, драматизацію для пояснення певних граматичних тем, скетчі й діаграми, які набагато краще допоможуть відчути мову. Синтезом здобутих граматичних навичок А.В. Фрисбі вважає учнівські твори, де воєдино 3’єднуються думки, лексичні одиниці й граматика.

Лексична компетентність формується, як зазначає А.В. Фрисбі, від час керованого вправляння, але, на його думку, недостатньо лише керувати процесом, учня потрібно зацікавити. Тільки за цієї умови відбувається злиття вправи з процесом вивчення; власне, учнівський інтерес стає стимулом й чинником активного сприйняття. Важливим, на думку педагога, $€$ введення нового мовного матеріалу на вже відомих учням ситуаціях спілкування. Активна діяльність учнів, за А.В. Фрисбі, стає “корінням” для набуття нових знань, “фоном”, на якому введення нових мовних одиниць природно вписується у ситуацію спілкування. Мета вчителя створювати цей “фон”, обирати розмовні теми й забезпечувати своїх учнів мовними засобами для їх обговорення. Лексичні одиниці, вжиті поза контекстом, певною мірою можуть існувати у репертуарі учня, але попри все, автор закликає до вивчення нових мовних одиниць у ситуаціях спілкування, природних для людей, які володіють цією мовою (Фрисбі, 1964, сс. 119-120).

Ця позиція А.В. Фрисбі є актуальною й корисною для сучасного педагога, про що свідчать й Методичні рекомендації щодо навчання розмовної мови. Обмеження кількості “мовного інвентарю”, з яким ознайомлюють учнів одночасно на одному уроці, до чотирьох-п'яти одиниць $€$ психологічно обгрунтованою рекомендацією (Методичні рекомендації, 2017). Досить сумнівно, що молодший школяр може одночасно засвоїти десять і більше слів й перетворити їх на засіб мислення, як це стається нині у реальному житті. Можливо, заклик А.В. Фрисбі до слідування принципу “менше - це більше” нарешті припинить “тортури”, яким піддаються сучасні діти, змушені зазубрювати десятки слів для написання ненависних диктантів, результатом чого стає страх і стійка нелюбов до іноземної мови.

Про актуальність твору А.В. Фрисбі свідчить його ставлення до ігрових методів навчання, оскільки він вважав їх не лише засобом мотивації, а й “способом навчання молодших школярів”, адже діти - активні, хочуть рухатись, бути задіяними в якусь діяльність й отримувати від неї результати (Фрисби, 1964, с.118). І всім зазначеним прагненням відповідають ігрові методи навчання. Крім того, гра відіграє багатозначну роль у навчальному процесі, адже сприяє не лише створенню мотивації, а й підсвідомому запам'ятовуванню слів й структур, навчає працювати в колективі, виховує потрібні для подальшого життя моральні якості, вчить впевненості в собі й культивує бажання досягати мети. Різноманіття ігор дає змогу використовувати їх на будьяких етапах уроку: на його початку - для активізації знань учнів і підготовки до подальшої роботи; між основними етапами уроку - для закріплення вивченого матеріалу й наприкінці для повторення пройденого матеріалу, розваги й відпочинку. Отже, ігри надають учням можливість бути фізично активними й водночас реалізовувати навчальні цілі уроку (Бабенко, 2005, cс. 153-164).

На особливу увагу заслуговує ставлення А.В. Фрисбі до помилок. За комунікативним методом, учитель не має припиняти або переривати мовлення учнів (й, особливо, непідготовленого), щоб у них не зникло бажання говорити. Типові помилки, які трапляються неодноразово, обговорюють пізніше, й учні практикуються в правильному вживанні проблемних структур або граматичних явищ. Натомість, А.В. Фрисбі наголошує на неприпустимості помилок й, виходячи з цих міркувань, дозволяє учням обмірковувати свої відповіді, перш, ніж їх озвучити. 
Таке ставлення до помилок вирізняє методику А.В. Фрисбі від комунікативного методу навчання й характеризує його як прихильника біхевіоризму, за яким помилка може призвести до формування поганої звички й, отже, підлягає негайному викоріненню.

Про своє бачення створення психологічно сприятливої атмосфери на уроці А.В. Фрисбі розповідає в розділі “Джон і я”, де зупиняється на докладному описі ролі вчителя, його обов'язків стостовно учня - головної особи навчального процесу. За А.В. Фрисбі, компетентність, упевненість, кооперація є складовими успіху, які допомагають створити на уроці атмосферу, прийнятну для засвоєння знань. Щодо учня, то тут увага наставника має бути максимальною: треба вивчати “природу дитини”, спостерігати реакцію учнів на все, що відбувається на уроці, помічати всі дрібниці й, відповідно, змінюватись самому, вносити корективи в перебіг уроку, в заплановані види й форми діяльності на уроці з тим, щоб підтримувати інтерес учнів і зробити процес навчання максимально ефективним. Дітям цікаво, коли зацікавлений учитель, стверджує автор. Оскільки більшість учителів англійської мови не є іï носіями, А.В. Фрисбі закликає їх до постійного вправляння в мовленні, вважаючи зупинку в розмовній практиці “фатальною” (Фрисбі, 1964, сс. 111-124). Ці вимоги не втратили своєї актуальності: вдосконалення професійної майстерності шляхом відвідування тренінгів, семінарів, професійних майстерень має стати неодмінним і постійним аспектом професійної діяльності кожного вчителя (Методичні рекомендації, 2017).

За А.В. Фрисбі, праця педагога є невід’ємною від його виховної діяльності й психологічних спостережень. Тому він вважає за необхідне вивчати й брати до уваги неоднорідні мовні здібності учнів, яких нараховується до п’ятдесяти ступенів. Крім того, він розрізняє інші відмінності між учнями, в основі яких лежать інтелектуальні (розумова спроможність до оволодіння іншою мовою), фізичні (зір, слух, артикуляція), психологічні (розвиток візуальної / слухової уяви; сором'язливість, байдужість до навчання), побутові (несприятливі домашні умови) й виховні особливості (антипатія до вчителя й методів його роботи) (Фрисбі, 1964, сс. 122-123).

Висловлюючись сучасною педагогічною термінологією, А.В. Фрисбі дотримується певних етапів процесу виховання: спостереження з метою вивчення дитини, виокремлення конкретних рис і властивостей особистості вихованця, діагностування й проектування його особистості на основі зразка (ідеалу). Лише після вивчення психологічних особливостей дітей можна успішно управляти процесом виховання, що передбачає доречне добирання змісту, форм, методів і прийомів виховання й навчання. Застосування різних видів діяльності на уроці, різноманіття навчальних вправ, надання дітям можливості бути фізично активними протягом уроку, використання ігрових методів, вміння долати емоційні перешкоди допомагають учителеві підтримувати увагу протягом усього уроку, запобігати проявам поганої поведінки й створювати атмосферу позитивної вмотивованості учнів.

Висновок. Погляди А.В. Фрисбі щодо навчання англійської мови молодших школярів не втратили актуальності. Особливо цінними надбаннями для сучасного вчителя можуть стати методи створення позитивної мотивації шляхом вправляння у непідготовленому мовленні на початку навчання; настанови щодо впровадження ігрових методів навчання; методичні рекомендації щодо введення й закріплення лексичних одиниць: від кількості, послідовності введення, фонетичного опрацювання - до повного усвідомлення значення лексичної одиниці й залучення iї до вправ в непідготовленому мовленні. Заслуговують на увагу й поради вчителеві щодо створення в класі сприятливої психологічної атмосфери, небайдужого ставлення до особистості кожного учня, вивчення й урахування психологічних особливостей дітей і постійного вдосконалення своєї методичної компетентності.

ЛIТЕРАТУРА:

Бабенко Т.В. (2005). Методика навчання англійської мови у початкової школі. Київ, Україна:

Арістей. Сc. 153-164. 
Гончаренко С.У. (1997). Украӥнський педагогічний словник. Київ, Україна: Либідь.

Методичні рекомендації щодо організації навчального процесу з іноземних мов у 1-х класах експериментальних загальноосвітніх навчальних закладів. №1/9-503 від 15.09.2017. Додаток до листа Міністерства освіти і науки України.

Рапацевич С.С. (2010). Золотая книга педагога : Справочное изд. А.П. Астахов (Ред.). Минск, Белоруссия : Современная школа. Сс. 327-332.

Якобсон П.М. (1969). Психиатрические проблемь мотивации поведения человека. Москва, Российская федерация: Просвещение.

Celce-Mursia M. (1991). Teaching English as a Second or Foreign Language. (Second Edition). Boston: Heinle\& Heinle Publishers.

Chapman, S. \& Routledge, P. (eds) (2005). Key Thinkers in Linguistics and the Philosophy of Language. Edinburgh: Edinburgh University Press. Pp. 80-86

Firth J. R. Personality and Language in Siciety (1950). The Sociological Review. (Volume a42, Issue 1). Pp. 37-52 - Retrieved from: https://doi.org/10.1111/j.1467-954X.1950.tb02460.x

Frisby A.W. (1964). Teaching English. Notes and Comments on Teaching English Overseas. Longmans, Green and CO LTD.

\section{REFERENCES}

Babenko T.V. (2005) Teaching methods of the English language in Primary school. Kyiv, Ukraine, Aristey. Pp. 153-164.

Honcharenko S.U. (1997). Ukrains'kyj pedahohichnyj slovnyk. Kyiv, Ukraina: Lybid'.

Metodychni rekomendatsii schodo orhanizatsii navchal'noho protsesu z inozemnykh mov u 1-kh klasakh eksperymental'nykh zahal'noosvitnikh navchal'nykh zakladiv. \#1/9-503 vid 15.09.2017. Dodatok do lysta Ministerstva osvity i nauky Ukrainy.

Rapacevich E.S. (2010). Zolotaja kniga pedagoga : Spravochnoe izd. A.P. Astahov (Red.). Minsk, Belorussija : Sovremennaja shkola. Cc. 327-332.

Jakobson P.M. (1969). Psihiatricheskie problemy motivacii povedenija cheloveka. Moskva, Rossijskaja federacija: Prosveshhenie.

Celce-Mursia M. (1991). Teaching English as a Second or Foreign Language. (Second Edition). Boston: Heinle\& Heinle Publishers.

Chapman, S. \& Routledge, P. (eds) (2005). Key Thinkers in Linguistics and the Philosophy of Language. Edinburgh: Edinburgh University Press. Pp. 80-86

Firth J. R. Personality and Language in Siciety (1950). The Sociological Review. (Volume a42, Issue 1). Pp. 37-52 - Retrieved from: https://doi.org/10.1111/j.1467-954X.1950.tb02460.x

Frisby A.W. (1964). Teaching English. Notes and Comments on Teaching English Overseas. Longmans, Green and CO LTD. 